\title{
Safety and efficacy of antimicrobial nanostructured textiles: comparison with 11070 national standard
}

\author{
Afrah Sepehr', Sepideh Arbabi-Bidgoli ${ }^{2}$ Seyyed Reza Hosseini Doost ${ }^{3}$, \\ ${ }^{I} \mathrm{MSc}$, Pharmaceutical Sciences Research Center, Tehran Medical Sciences, Islamic Azad University (IAUTMU), Tehran, \\ Iran \\ ${ }^{2}$ Professor, Department of Toxicology, Faculty of Pharmacy, Tehran Medical Sciences, Islamic Azad University \\ (IAUTMU), Tehran, Iran \\ ${ }^{3}$ Professor, Department of Microbiology, Faculty of Advance Sciences and Technology, Tehran Medical Sciences, \\ Islamic Azad University (IAUTMU), Tehran, Iran
}

\begin{abstract}
Background: This study aimed to evaluate the efficacy and safety of five randomly selected nanostructured products by the National Standard of No. 11070.

Materials and methods: Antibacterial activities of five different nanostructured textiles were assessed on specific microorganisms to human skin and environment. The physicochemical properties were determined by FTIR spectrum and the dermal toxicity was assessed by skin and eye irritation and corrosion test (OECD 404,405).

Results: Each of the 5 samples at concentrations of $0,0.5,1,1.5,2$ and $5 \%$ had strong antibacterial activity compared to control treatments. Mild and reversible irritations were observed at all three concentrations of nanosilver $(5,50$, and $500 \mathrm{ppm})$ after 24 hours exposing to yarn and tissue samples on female rabbits, and the FTIR test related to 5 products showed no change in group, before and after the treatments e.g. washing and contact with the test animals (rabbits). Tissues containing nano-silver particles had no irritating effect and eye lesions in rabbits.

Conclusion: According to the results, in addition to complying with the properties mentioned in the health license, the nanostructured textiles complied with the standard features of 11070.

Keywords: Nanostructured textiles, Skin, irritation, Corrosion, Effects, Antimicrobial effects.

Cited as: Sepehr A, Hosseini Doost SR, Arbabi-Bidgoli S. Safety and efficacy of antimicrobial nanostructured textiles: Comparison with 11070 national standard. Medical Science Journal of Islamic Azad University, Tehran Medical Branch 2020; 30(2): 174-184.

Correspondence to: Sepideh Arbabi-Bidgoli

Tel: +982188003470

E-mail: s.arbabi@iautmu.ac.ir

ORCID ID: 0000-0003-4830-8680

Received: 20 May 2019; Accepted: 3 Sep 2019
\end{abstract}


مجله علوم يزشكى دانشگاه آزاد اسلامى

دوره • r، شماره ז، تابستان 99، صفحات IVF

Original

Article

\title{
بررسى مقايسهاى وضعيت شاخصهاى ايمنى منسوجات نانوساختار داراى اثر ضد ميكروبى با شاخصهاى تعريف شده در استاندارد ملى •V • •ll ايران
}

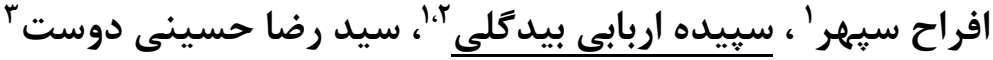

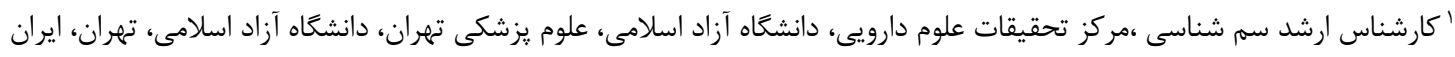

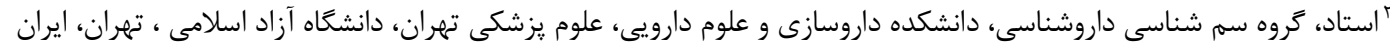

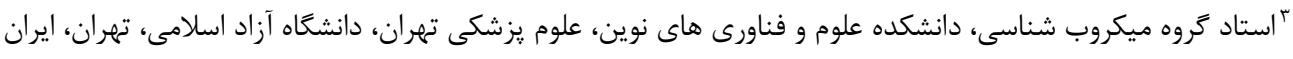
جـكده

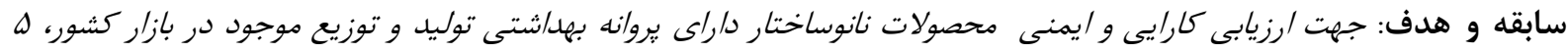

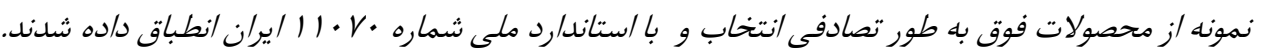

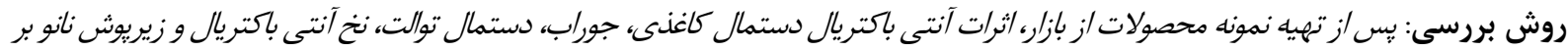

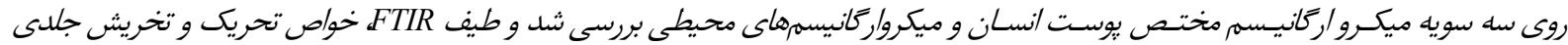

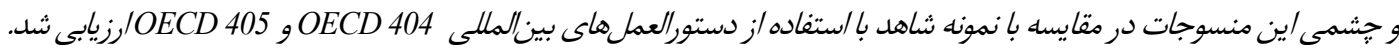

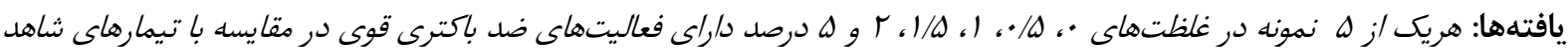

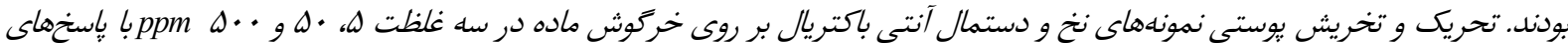

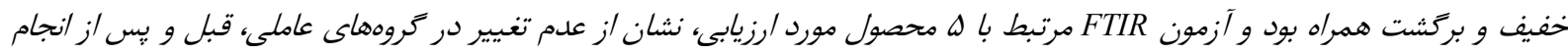

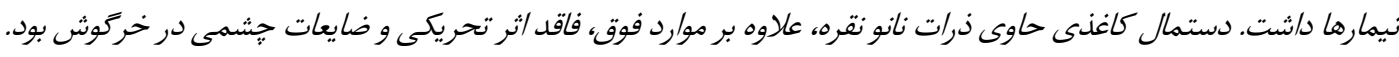

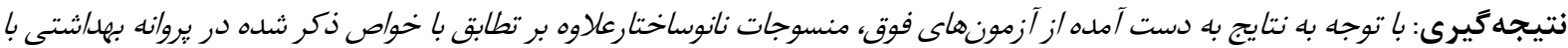

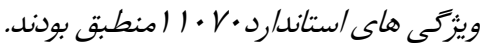

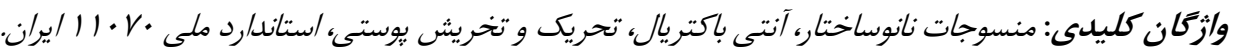
كارآيى بالا، فرايند هاى رو به رشدى را در جهت كاربردهاى مقلهمه

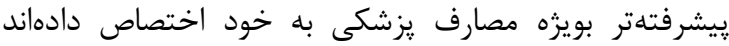

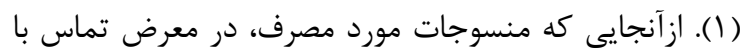

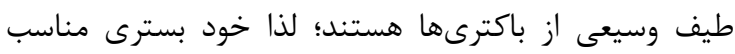

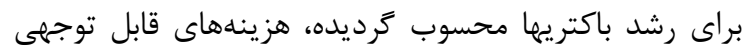

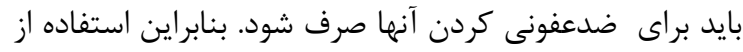

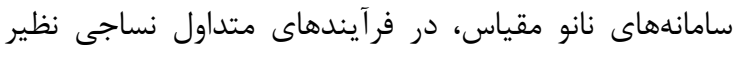

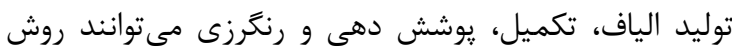

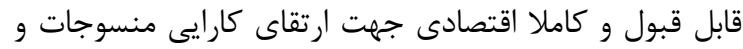

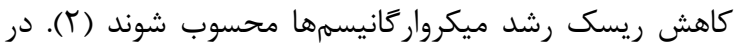
واقع، امروزه صنعت نساجى به يكى از زمينههاى اصلى براى امروزه استفاده از نانو مواد و فناورى نانو در صنايع مختلف از

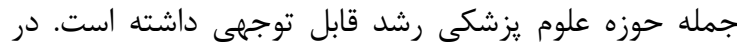

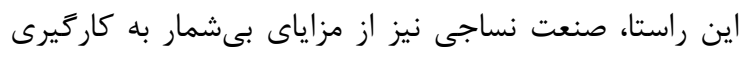

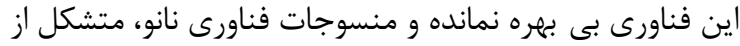

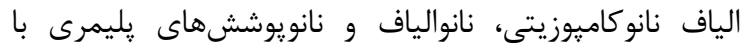

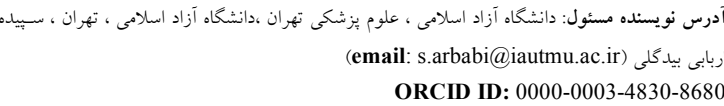

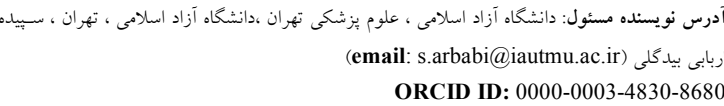

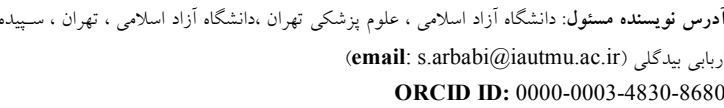
تاريخ دريافت مقاله:

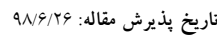




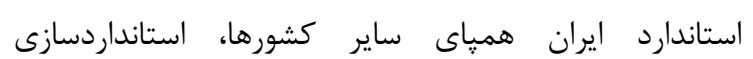

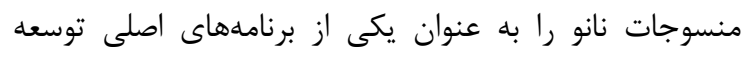

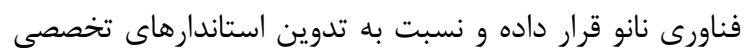

$$
\text { اين حوزه اقدام كند (و، هارئ }
$$

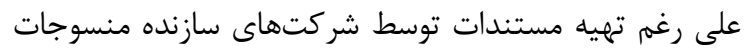

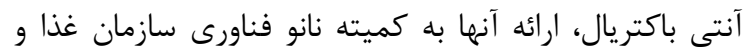

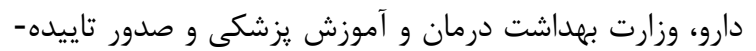

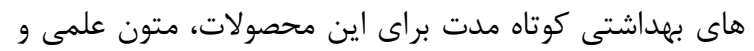

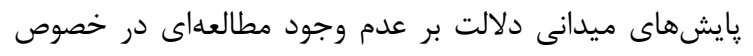

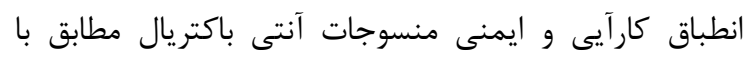

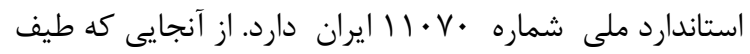

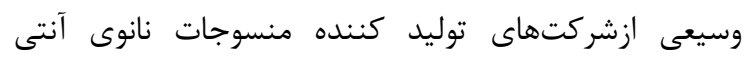

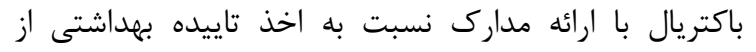

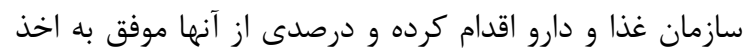

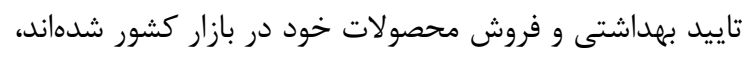
هدف از انجام اين تحقيق، بررسى كيفيت اين محصولات يس

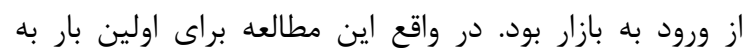

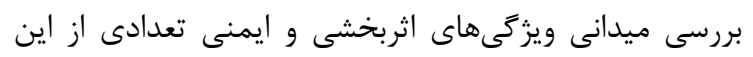

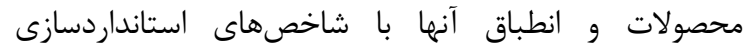

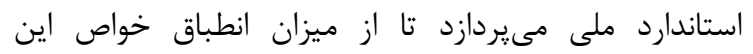

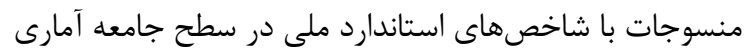
موردنظر، اطمينان حاصل كردد.

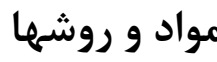

اين بررسى يك ارزيابى آزمايشكاهى با نمونهبردارى ميدانى از

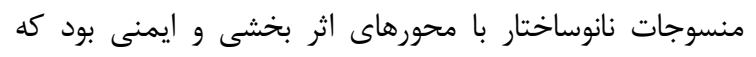

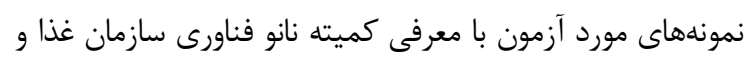
دارو به شرح ذيل انتخاب شدند: ا-لباس زير تهيه شده از نخ آنتى باكتريال r-زيريوش آنتى باكتريال

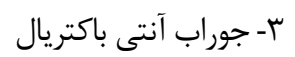

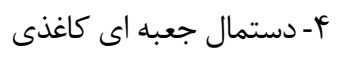
ه-دستمال توالت

اين محصولات به عنوان معرف خواص مجموعه منسوجات

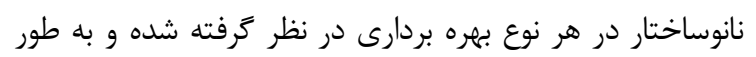

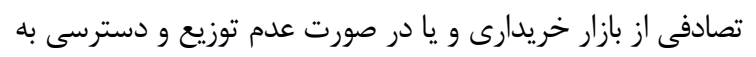

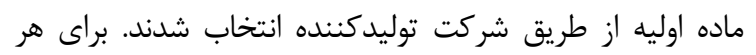
نمونه انتخاب شده، در تمام مراحل آماده سازى و و آناليز نمونه،

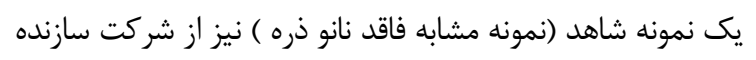

كاربرد فناورى نانو در توليد محصولات و بهبود فرآيندها تبديل

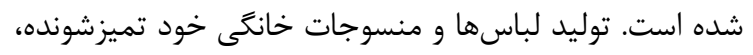

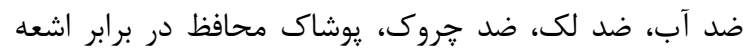

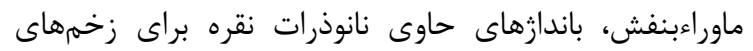

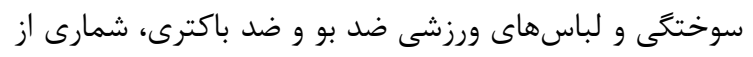
تحولات ايجاد شده در صنعت نساجى با كمك فئ فناورى نانو

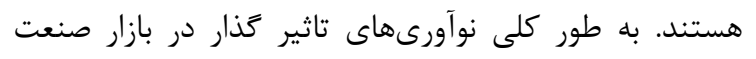

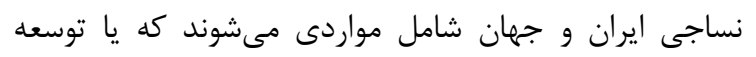

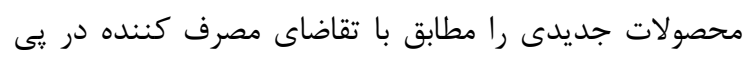

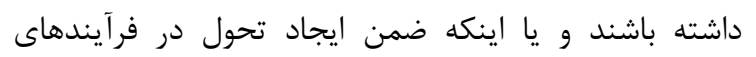

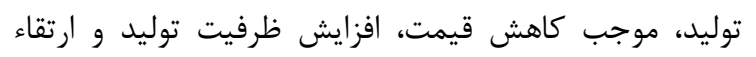

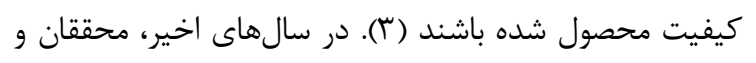

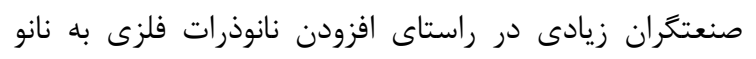

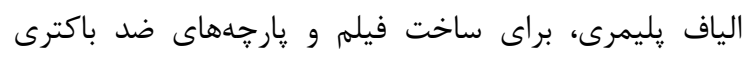

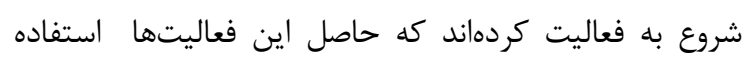

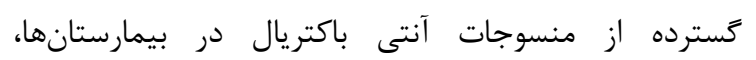

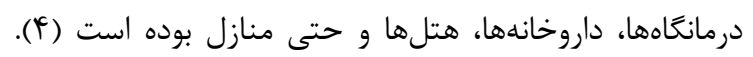

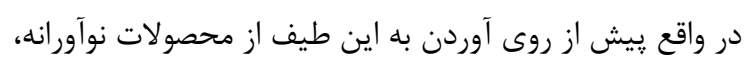

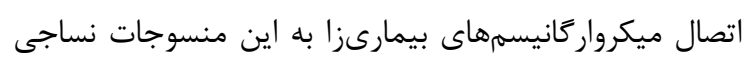

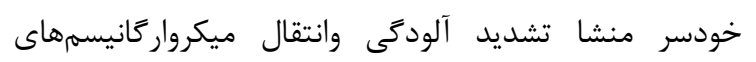

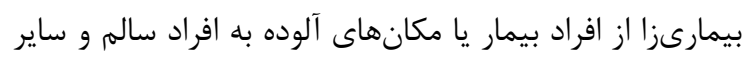

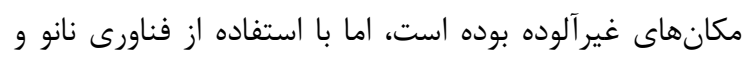

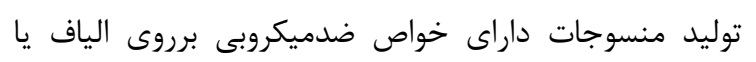

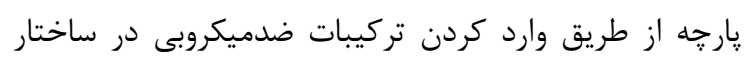

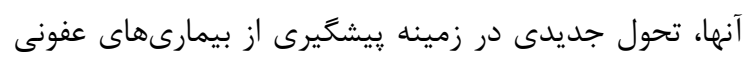

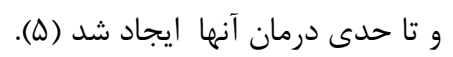

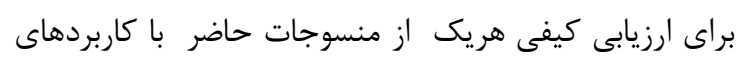

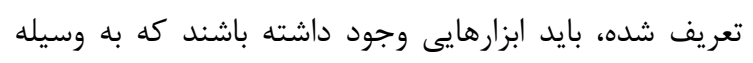

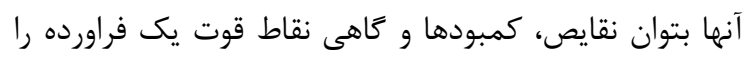

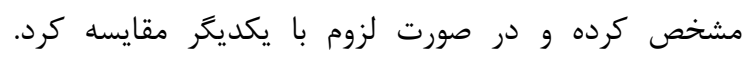

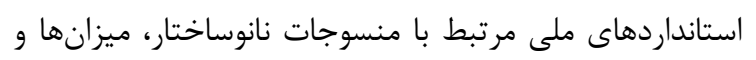

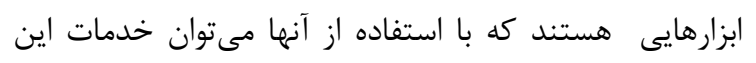

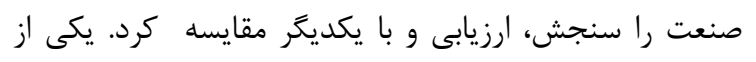

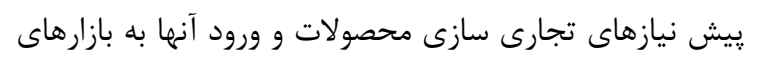

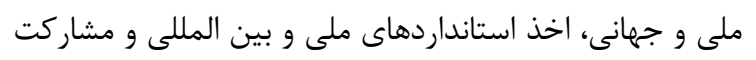

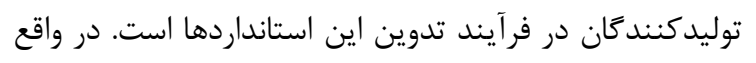

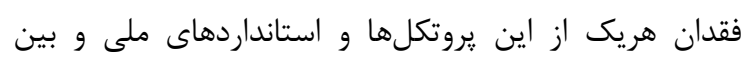
المللى مربوط به روشهاى انديك اندازه كيري، كارآيى و و خواص

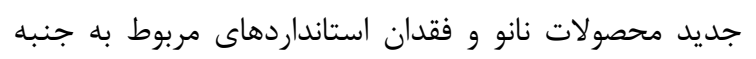
هاى ايمنى اين نوع محصولات، موجب شده است كه سازمان اسن 
استاندارد، از هريك از لولههاى فاقد رشد، •له ميكروليتر نمونه

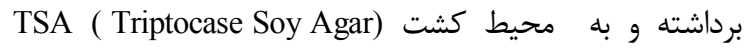

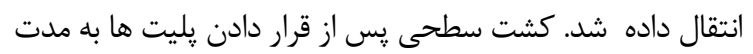
يك شب در دماى 9V درجة سانتى

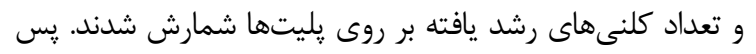

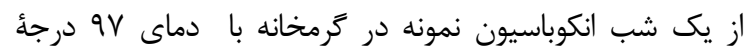
سانتى گراد، يليتى كه حاوى رقيقترين محلول كلوئيدال بود و در

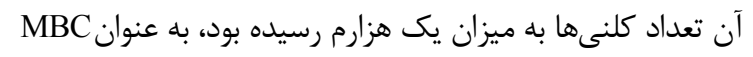
در نظر گرفته شد (1) (1). بررسى اثر ضد ميكروبى الياف و منسوجات نانوساختار بر باكترىهاى مورد آزمون در اين آزمايش از روش رقت لولهاى و قطره پيليت براى شمارش

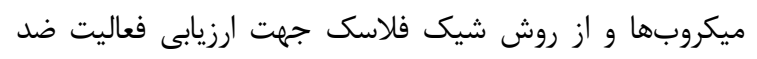
ميكروبى الياف معمولى و نيز الياف ضدميكروبى با درصدهاى

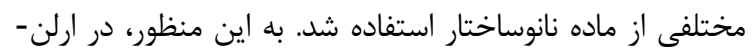

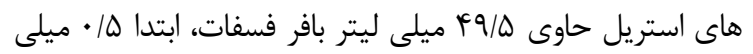
ليتر از باكترى موردنظر با غلظت مشخص(CFU/ml 105 x5/1)

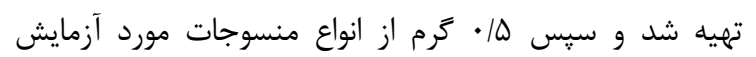
اضافه شد. آنغاه با مخلوط كردن در زمان صفر، اولين رقت مناسب از سوسيانسيون حاصل شد. به منظور شمارش كلنىها به

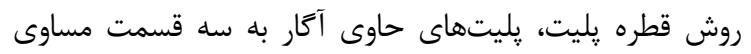

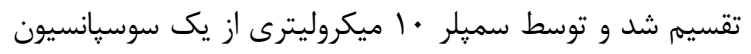

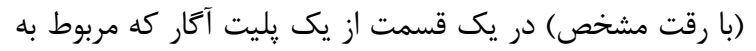

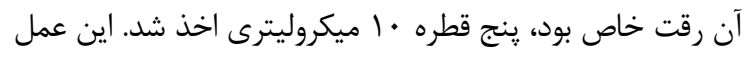

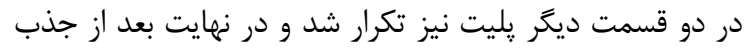

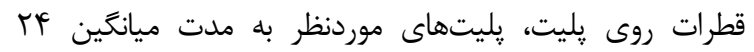

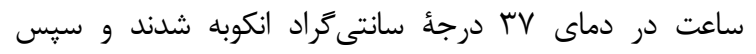
شمارش كلنىها صورت گرفت. به منظور شمارش كلنى بعد از

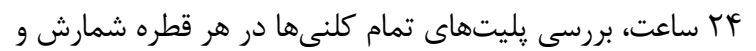

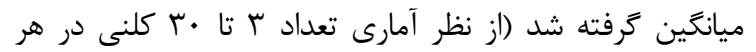

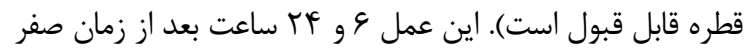

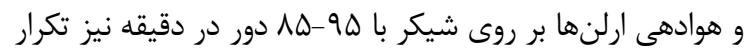

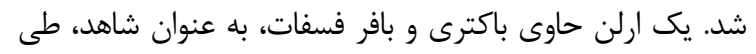

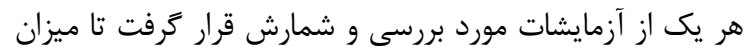
رشد هر يك از باكترىها در بافر فسفات نيز مشخص شود (I I). تست هاله براى بررسى خاصيت ضد باكترى منسوجات نانوساختار نسبت به

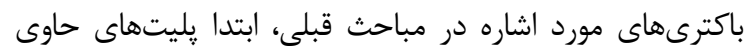
محيط كشت مربوطه به صورت شطرنجى كشت داده شد و و بلافاصله نمونه پارجه موردنظر در سطح يليت قرار گرفته و يليت
درخواست شد و با همكارى داوطلبانه ايشان تهيه و تحويل شد.

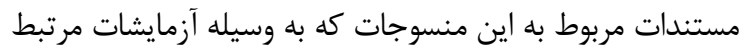
با شاخصهاى فيزيكوشيميايى، ميكروبى و سميت تهيه شده بود عمدتا تكرار و مورد تجزيه و تحليل قرار گرفت. در نهايت نتايج به به بهيه

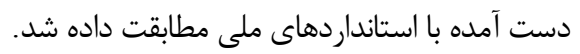

آزمون

به منظور بررسى تغييرات ساختارى در بين گروههاى عامل حاصل از الياف نانوساختار موجود در اين منسوجات، يس از بر

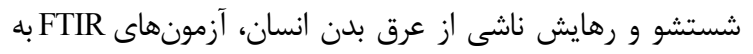

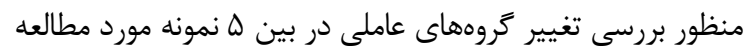
در اثر اين تيمارها و همجنين نمونه شاهد انجام شد. طيف FTIR

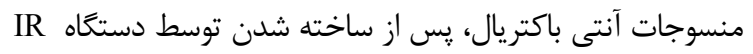
prestige 21

$$
\text { يتاسيم برومايد خشك ثبت شد (V، ^). }
$$

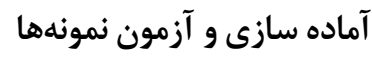

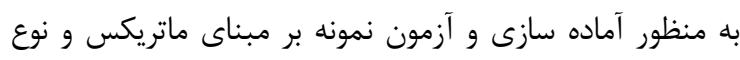
نانوذره به كار رفته، از استانداردهاى ملى و بين المللى مرتبط در

$$
\text { اين زمينه استفاده شد (9، •(1). }
$$

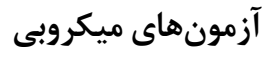

محيط كشت و باكترى هاى استفاده شده

سويههاى باكترى استفاده شده در اين آزمايش شامل موارد ذيل

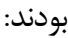

PTCC III - 11 PTCC باشريشياكلى •rسا

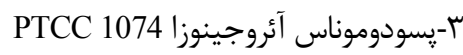

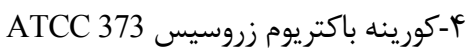
باكترىهاى نام برده از مركز كلكسيون ميكرواركانيسمهاى زئس صنعتى ايران وابسته به يزوهشكده زيست فناورى سازمان يُوهشهاى علمى و صنعتى ايران (IROST) تهيه شدند. آميول

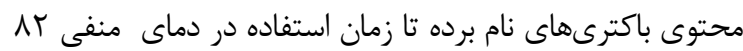
درجه سانتى

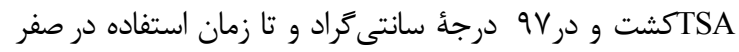

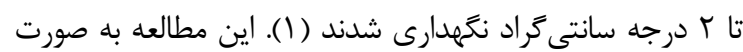

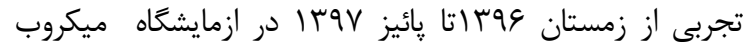
شناسى مركز تحقيقات علوم دارويى واحد علوم دارويى دانشخاه

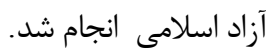

\section{روش تعيين حداقل غلظت باكترى كشى} (Minimum Bactericidal Concentration) در روش استاندارد (مرجع) يس از انجام تست رقيق سازى و

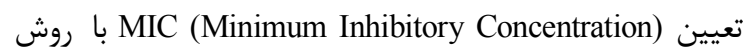




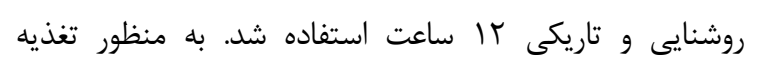

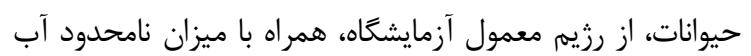

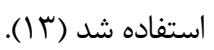

انجام آزمون

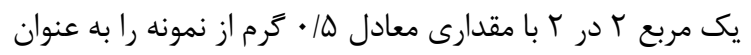
آزمونه روى قسمت كوخكى از يوست (تقريبا ه سانتيمتر) قرار

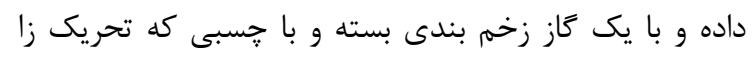

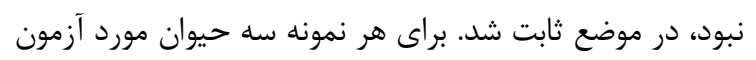

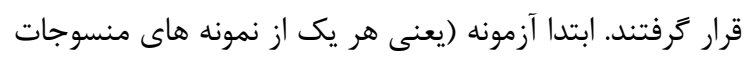

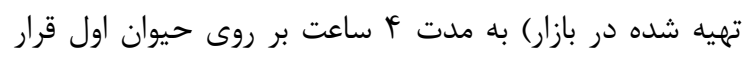

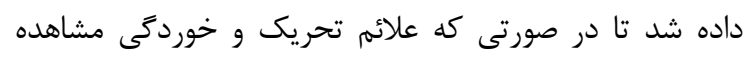

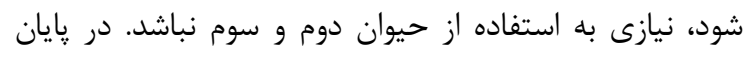

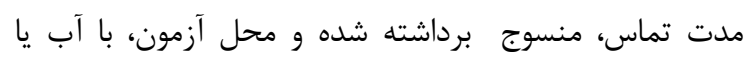

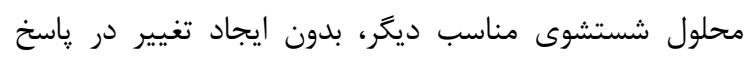

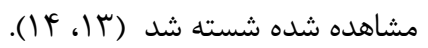

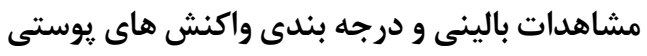

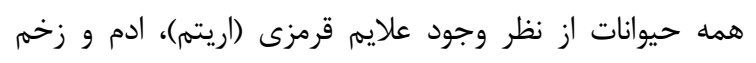

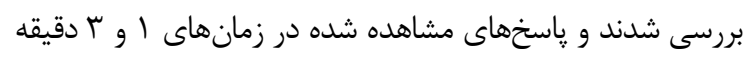

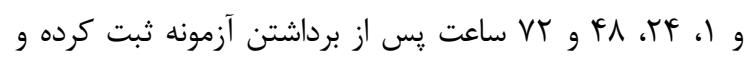

$$
\text { تحليل آمارى شدند (با) آل }
$$

به منظور جمع آورى نمونهها از شركتهاى توليد كننده و ياري

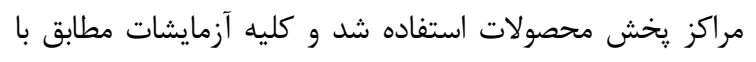

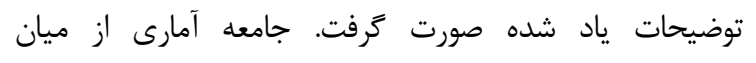

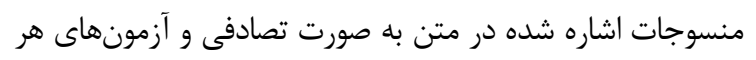

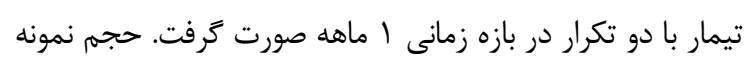

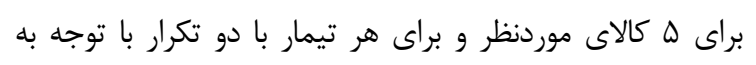

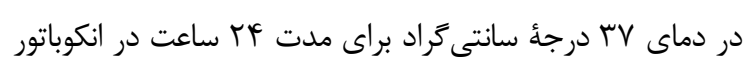

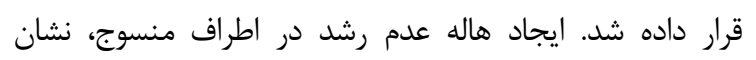

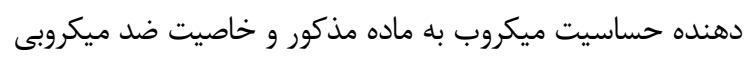

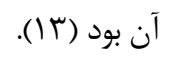

بر رسى عوارض ناشى از تماس يوستى (1/)

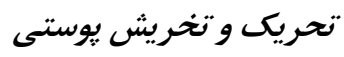

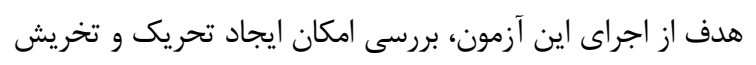

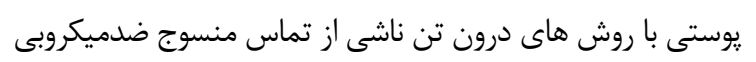

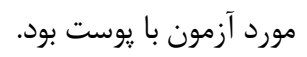
تحريك و تخريش بوسنى - روث آزمون درون تن اساس آزمون نمونه نهايى آزمايشخاهى مورد آزمون مستقيم روى يوست خركوش

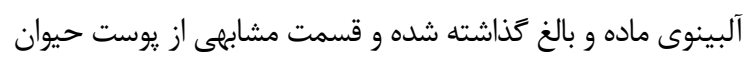
كه مورد تيمار قرار نكرفته، به عنوان كنترل مورد استفاده قرار كرفت، يعنى از سطح مجاور بدن حيوان به عنوان شاهد استفاده

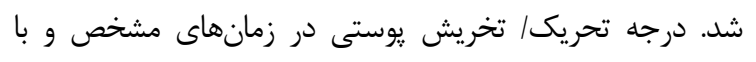

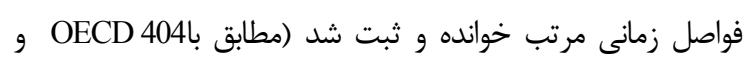

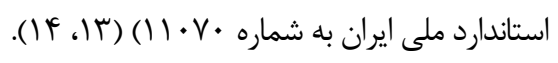

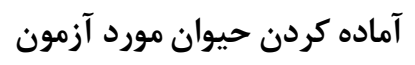
از خركوش آلبينو بالغ به عنوان حيوان مورد ازمون مورد آزمون استفاده شد و

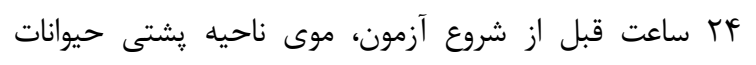

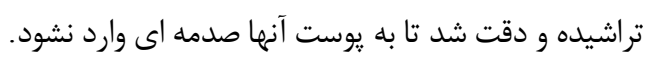
شرايط نكَهدارى و تغذيه حيوانات مورد آزمون

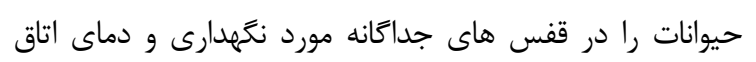

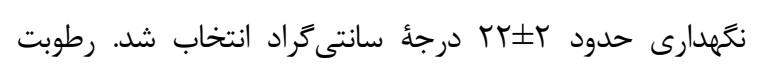

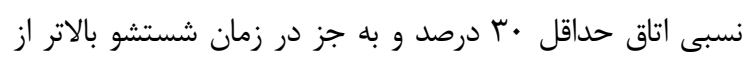

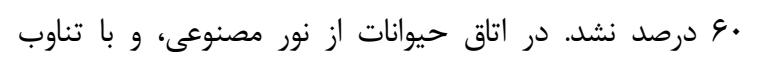

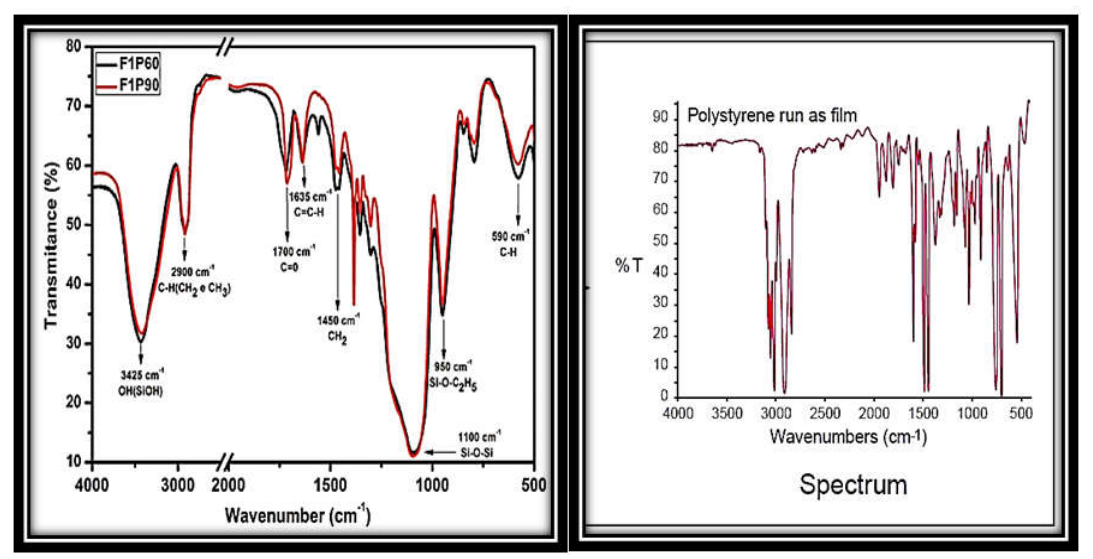

شكل ا. نمونهاى از طيف تبديل فوريه مادون قرمز (FTIR) كروه هاى عاملى مرتبط با جوراب آنتى باكتريال، قبل و بعد از انجام • إبار شستشو (نمونه شاهد و تيمار شده) 
ليتر باكترى اشرشيا كلى، پسودوموناس آئروجينوزا و آزمونهاى مورد بررسى •ل نمونه و تيمار به همراه نمونه شاهد استافيلوكوكوس اورئوس در سطح TSA كه به طور جداگانه

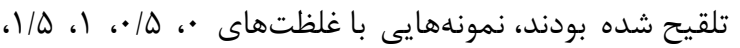

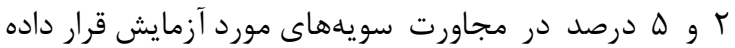

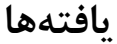

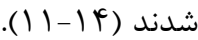

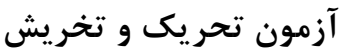

\section{طيف FTIR براى منسوجات نانوساختار}

در بخش مقايسه با استاندارد و نتايج حاصله از آنه آن، با توجه به شواهد قبلى در خصوص نخ آنتى باكتريال مورد مصرف داصن

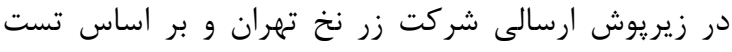

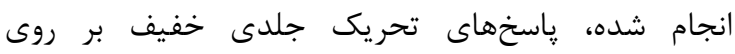

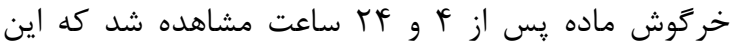

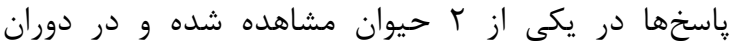

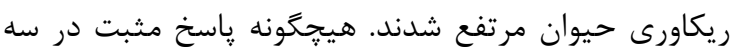
بخش قرمزى، زخم و ادم در حيوانات مورد آزمون ديده

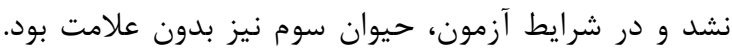

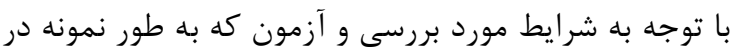
اينجا به منظور آشنايى با نحوه تطابق با استاندارد و نمونه

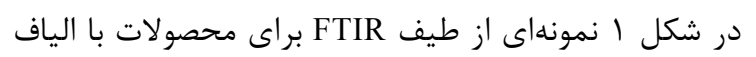

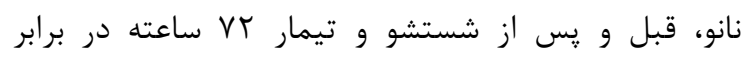
رهايش با عرق نمايش داده شده است. در مقايسه نمونه

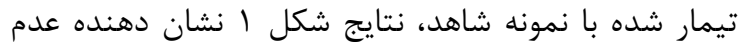

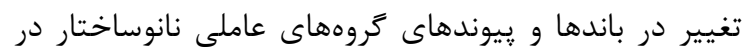

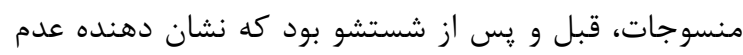
تغييرات شيميايى و تغييرات در ساختار باندها در اثر دئر

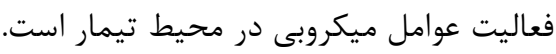

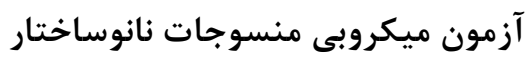

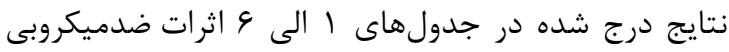

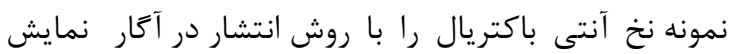

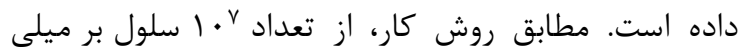

جدول ا. نتايج آزمايشات ميكروبى مرتبط با اثرات آنتى باكتريال نخ پِ از ـ إبار شستشو

\begin{tabular}{|c|c|c|}
\hline اشرشيا كولى & استافيلوكوكوس اورئوس & نوع باكترى \\
\hline TDQTT & rDqTR & شماره سويه \\
\hline $1 / \Delta \times 1 \cdot \wedge$ & $1 / 0 \times 1 \cdot 1$ & غلظت مايه تحقيق (CFU/ml) \\
\hline $1 \cdot \mathrm{cc}$ & $1 \cdot c c$ & حجم مايع تزريقى \\
\hline$\Delta \times 1 \cdot \wedge$ & $\Delta \times 1 \cdot 1$ & حجم باكترى در سوسيانسيون اوليه \\
\hline$r \times 1 \cdot r$ & $r \times 1 \cdot{ }^{r}$ & تعداد سلول باكترى (يس از VT ساعت) \\
\hline SOP & SOP & روش اندازه كيرى \\
\hline 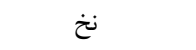 & 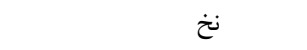 & نوع ماده نمونه \\
\hline اتوكلاو & اتوكلاو & روش سترون سازى \\
\hline 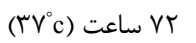 & rV ساعت (TV & زمان كرمخانه كَذارى \\
\hline
\end{tabular}

جدول r. نتايج آزمايشات ميكروبى مرتبط با اثرات آنتى باكتريال جوراب مهيار (ادعاى شركت: حاوى ٪× ن نانو)

\begin{tabular}{|c|c|c|}
\hline 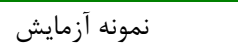 & نمونه كنترل & نوع باكترى (يسودوموناس آئروجينوزا) \\
\hline ATCC15442 & ATCC15442 & شماره سويه \\
\hline$F \times 1.9$ & $4 \times 1.9$ & غلظت مايه تحقيق (CFU/ml) \\
\hline $1 \cdot c c$ & $1 \cdot \mathrm{cc}$ & حجم مايع تزريقى \\
\hline$r \times 1 \cdot r$ & $r \times 1.0^{9}$ & تعداد سلول باكترى (يس از YY ساعت) \\
\hline- & $r / \Delta \times 1 .{ }^{9}$ & تعداد سلول باكترى بلافاصله پِ از تلقيح \\
\hline 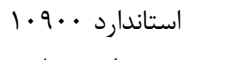 & استاندارد . .9. & روش اندازه كيرى \\
\hline جـوراب مهيار & جوراب مهيار & نوع ماده نمونه \\
\hline 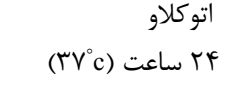 & 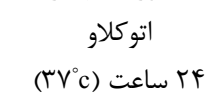 & زروش كَمخرون سازى كارى \\
\hline
\end{tabular}




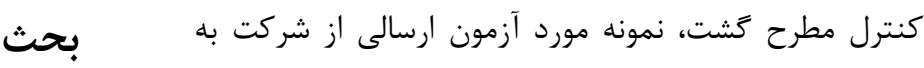

مطالعات متعدد در خصوص ايمنى مواد اوليه و محصولات نانو

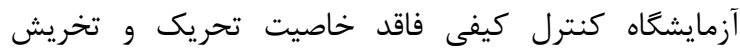

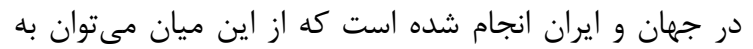

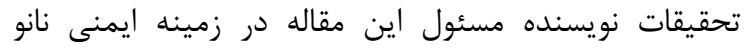

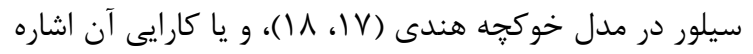
كرد (9). اما براساس اطلاعات موجود اين اولين مطالعه

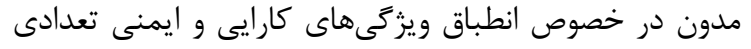

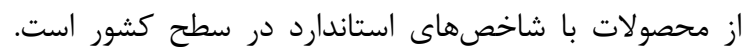

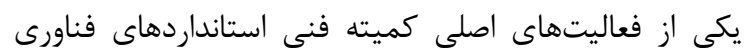
نانو، تدوين استانداردهاى ملى با توجه به اولويتها و نيازهاى كشور است. با توجه به حجم فزاينده معرفى منسوجات آنتى باكتريال

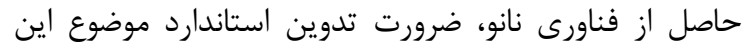

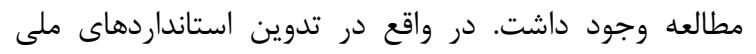

جلدى ارزيابى كشت و نتايج اين بخش از مطالعه مطابق با

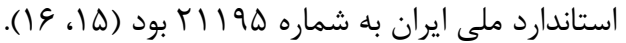

تستهاى سميت مخاطى و حساسيت جشمى (مطالعه موردى: دستمال كاغذى و توالت حاوى نانوذرات نقره)

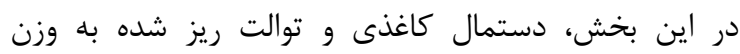

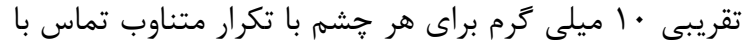

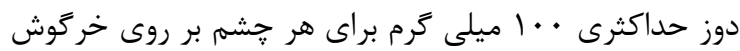

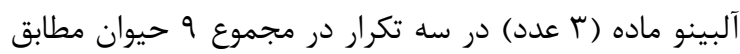

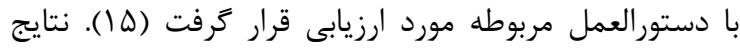

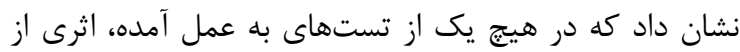
تحريك و تخريش جشمى در 9 حيوان مورد آزمون مشاهده

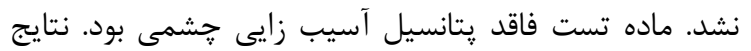

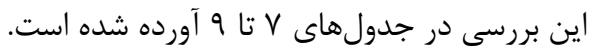

جدول r. نتايج آزمايشات ميكروبى مرتبط با اثرات آنتى باكتريال زيريوش مهنام (ادعاى شركت: حاوى •ب ٪ الياف نانو)

\begin{tabular}{|c|c|c|}
\hline 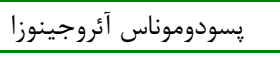 & 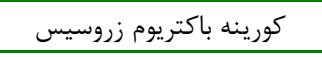 & 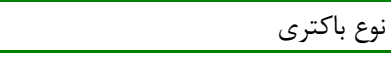 \\
\hline \multirow{11}{*}{ 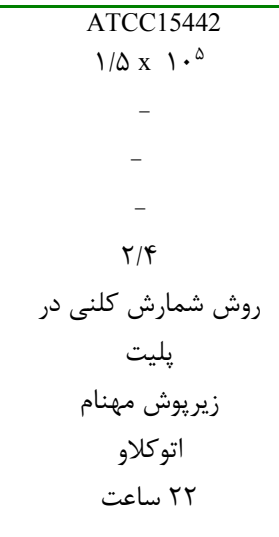 } & Skin isolate & شماره سويه \\
\hline & $1 / 0 \times 1.0$ & غلظت مايه تحقيق (CFU/ml) \\
\hline & $-\cdot / 11$ & مقدار رشد (F=lgC \\
\hline & $-r / \Delta$ & مقدار رشد (G=lg Ti-LgT) \\
\hline & T/RT & مقدار فعاليت ضد باكتريايى (A=F-G) \\
\hline & روش شمارش كلنى در & 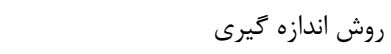 \\
\hline & بليت & \\
\hline & زير يوش مهنام & نوع ماده نمونه \\
\hline & اتوكلاو & 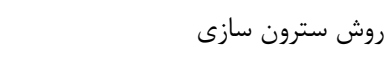 \\
\hline & (TV & زمان كَرمخانه كَذارى \\
\hline & 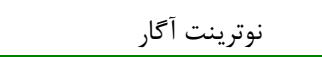 & محيط كشت \\
\hline \multicolumn{3}{|c|}{ *روند كاهش باكترى در اين نمونه ها بسيار سريع و از لحاظ آمارى معنى دار است (ه./•>p). } \\
\hline \multicolumn{3}{|c|}{ جدول F. نتايج آزمايشات ميكروبى مرتبط با اثرات آنتى باكتريال دستمال (كاغذى) } \\
\hline 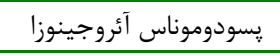 & اشريشيا كلى & نوع باكترى \\
\hline ATCC15442 & Skin isolate & شماره سويه \\
\hline $1 / \Delta * 1 . \Delta$ & $1 / 4 \times 1.0$ & غلظت مايه تحقيق (CFU/ml) \\
\hline- &.$- / 19$ & مقدار رشد (F=lgC \\
\hline- & $-r / Q$ & مقدار رشد (G=lg Tt-LgT) \\
\hline- & T/MT & مقدار فعاليت ضد باكتريايى (A=F-G) \\
\hline 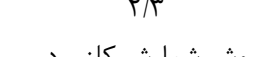 & روش شمارش كلنى در & روش اندازه كيرى \\
\hline روش شمارش كلنى در & ي رِليت & \\
\hline 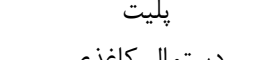 & 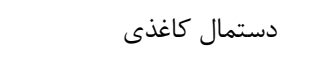 & نوع ماده نمونه \\
\hline داتمال كاغذى & اتوكلاو & روش سترون سازى \\
\hline ك اتوكلاو & ז Tاعت (TV'c) & زمان كرمخانه ََذارى \\
\hline 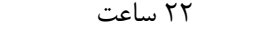 & ن نوترينت آكار & محيط كشت \\
\hline
\end{tabular}


جدول ه. نتايج آزمايشات ميكروبى مرتبط با اثرات آنتى باكتريال دستمال (توالت)

\begin{tabular}{|c|c|c|c|}
\hline يسودوموناس آئروجينوزا & استافيلوكوكوس اورئوس & اشرشيا كلى & نوع باكترى \\
\hline ATCC15442 & ATCC6538 & ATCC1053 & شماره سويه \\
\hline $1 / \Delta \times 1 . \Delta$ & $1 / 0 \times 1 . \Delta$ & $1 / \Delta \times 1 . \Delta$ & غلظت مايه تحقيق (CFU/ml) \\
\hline Igr & Igr & Igr & حجم آزمونه كنترل \\
\hline 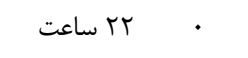 & 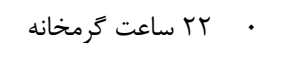 & T اعت گرمخانه حذارى & اختلاف نهايى بَ آزمونه(ساعت) \\
\hline$\cdot / 4 \quad \cdot / r$ & $\cdot / \Delta \cdot / 4$ & $\cdot / 4 \cdot / \mu$ & \\
\hline$+f / r$ & $+r / r$ & $+r / T$ & مقدار رشد (F=lgC \\
\hline$+t$ & $+\cdot / 1$ & $+1 / 4$ & مقدار رشد (G=lg Tt-LgT) \\
\hline$r / r$ & $r / \mathcal{F}$ & r & مقدار فعاليت ضد باكتريايى (A=F-G) \\
\hline شمارش كلنى در يليت & شمارش كلنى در ريليت & & روش اندازه كيرى \\
\hline دستمال & دستمال & & نوع ماده نمونه \\
\hline 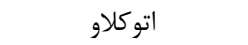 & اتو كلاو & & روش سترون سازى \\
\hline r r ساعت (rV & r T & & زمان گرمخانه كذارى \\
\hline
\end{tabular}

\begin{tabular}{|c|c|c|}
\hline استافيلوكو كوس اورئوس & استافيلوكو كوس اورئوس & نوع باكترى \\
\hline rDqYT & TDQTT & شماره سويه \\
\hline $1 / 9 * 1.9$ & $1 / 9 * 1.9$ & غلظت مايه تحقيق (CFU/ml) \\
\hline $1 \cdot \mathrm{cc}$ & $1 \cdot \mathrm{cc}$ & حجم مايع تزريقى \\
\hline R. $\log =2.6 ; 82.89 \%$ & R.Log $=2.6 ; 82.89 \%$ & حجم باكترى \\
\hline Sاخلى SOP & SOP & روش اندازه گيرى \\
\hline جوراب & دستمال & نوع ماده نمونه \\
\hline ع اتوكلاو & اتوكلاو & روش سترون سازى \\
\hline 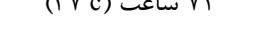 & ساعت (rV V & زمان گرمخانه كذارى \\
\hline
\end{tabular}

بر اساس مطالعات FTIR، مشاهده ثبات محصولات دلالت بر

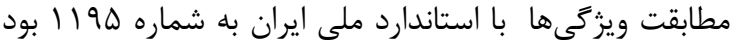

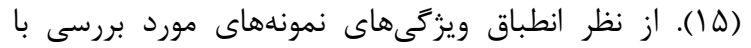

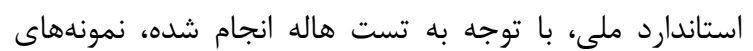
دستمال كاغذى ودستمال توالت بررسى شده، داراى بيشترين

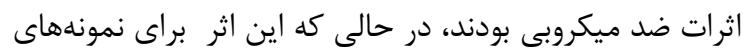

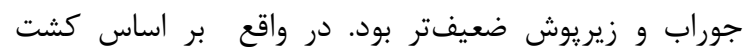

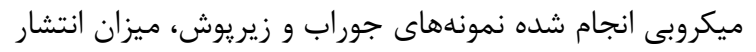

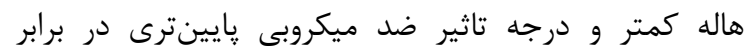

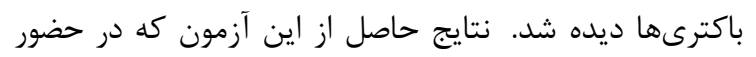

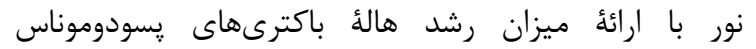

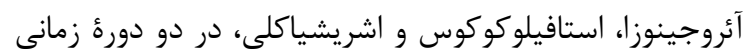

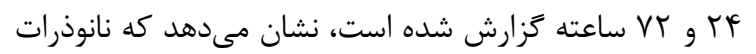

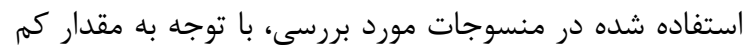

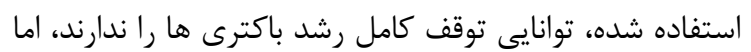
باعث كند شدن فرآيند رشد باكترىها در نمونههاى ساخته

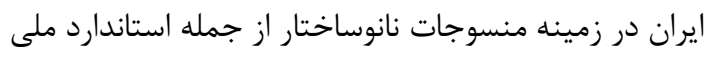

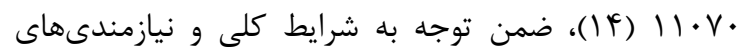

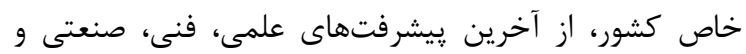

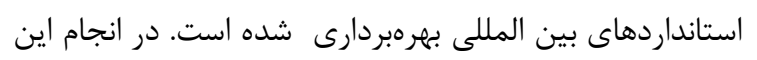

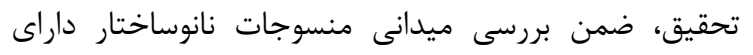

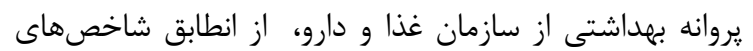

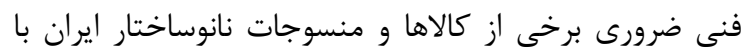

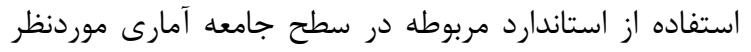

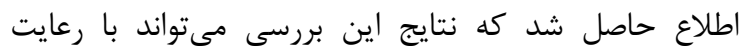

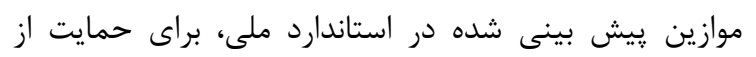

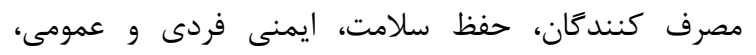

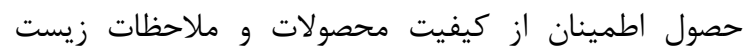

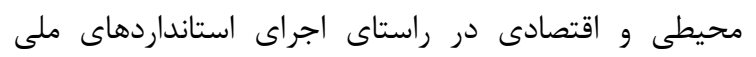
تدوين شده براى محصولات توليدى داخل كشور و يا اقلام

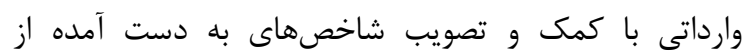
مطالعه، مورد استفاده قرار كيرد. 


\begin{tabular}{|c|c|}
\hline 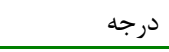 & قرنيه \\
\hline & 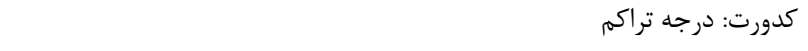 \\
\hline+ & 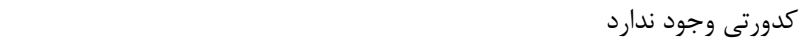 \\
\hline- & مناطق ״راكنده يا مختصرى از كدورت: جزئيات عنبيه قابل تشخيص است \\
\hline- & منطقه شفافى كه براحتى قابل تشخيص است: جزئيات عنبيه مختصرى محو شده \\
\hline- & منطقه شفاف و براق: جزئيات عنبيه مختصرى محو شده \\
\hline- & قرنيه كدر: عنبيه را در يشت كدورت نمى توان مشاهده كرد \\
\hline 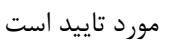 & 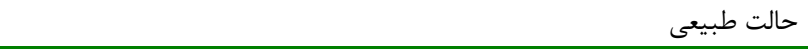 \\
\hline
\end{tabular}

جدول ^. نتايج آزمايشات درجه بندى بر اساس ضايعات جشمى (دستمال كاغذى و توالت)

\begin{tabular}{|c|c|}
\hline 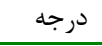 & قرنيه \\
\hline & ملتحمه \\
\hline 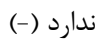 & سرخى (به ملتحمه يُلكى و مربوط به غير از قرنيه و عنبيه) \\
\hline+ & 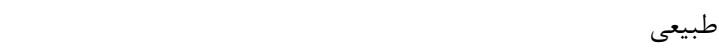 \\
\hline 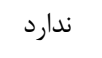 & مختصرى يرخونى عروق \\
\hline 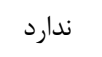 & رنغ قرمز يررنغ بصورت منتشر: عروق را به آسانى نميتوان تشخيص داد \\
\hline 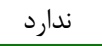 & رنى قرمز كوشتى منتشر \\
\hline
\end{tabular}

جدول 9. نتايج آزمايشات درجه بندى بر اساس ضايعات جشمى (دستمال كاغذى و توالت)

\begin{tabular}{|c|c|}
\hline 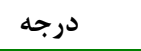 & قرنيه \\
\hline 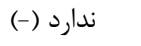 & تورم (مربوط به يلك يا يرده هاى يوشاننده) \\
\hline- & تورم مختصرى از حد نرمال \\
\hline 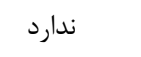 & تورم مشهود و واضح همراه با بركشتن يلك ها به خارج \\
\hline 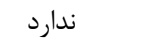 & تورم همراه با نيمه بسته شدن يلك ها \\
\hline 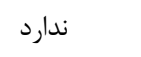 & تورم همراه با بسته شدن بيشتر رֶك ها \\
\hline $1 r r \pm r \& \Delta S$ & ميانكَين وزنى خركوش ها در طى آ روز \\
\hline
\end{tabular}

جذب اتمى تحويل داده شد، نشان دهنده تطبيق آن با

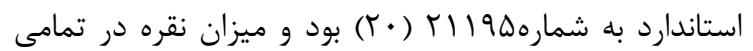

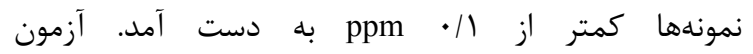
ميكروبيولوزيكى كه مههمترين آزمون در اين يروزةه محسوب

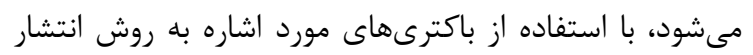
در محيط آكار، در دو شرايط متفاوت، يكى در حضور نور مرئى

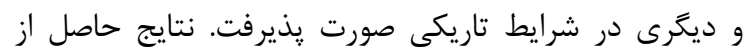

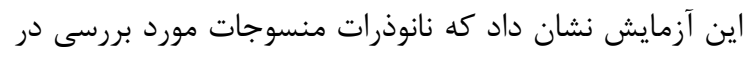

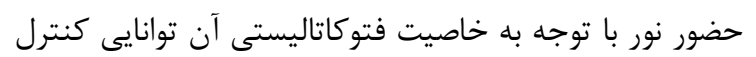

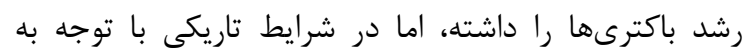

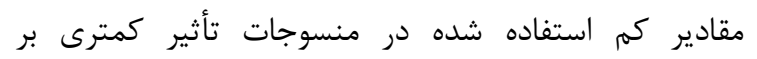
جلوگيرى از رشد باكترى دارند.

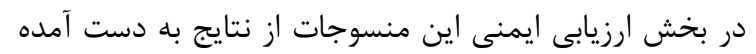

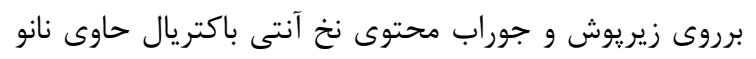
ذره نقره، توليد شركت زرنخ تهرئ ورون به منظوري
شده مىشوند و اين توانايى با افزايش مقدار و درصد نانوذرات

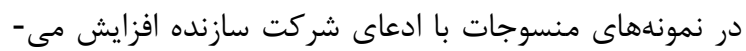

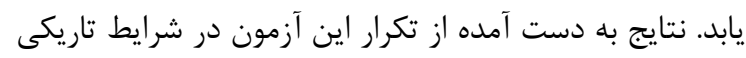
تأثير جندانى را در كنترل و كند كردن رشد و و تكثير ميكرواركانيسهها نشان نداد كه دليل اصلى آن مئن مكانيسم اثر نانوذرات باشد (IV). درواقع، اكسيداسيون

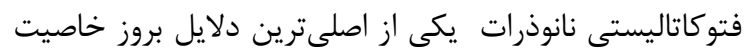

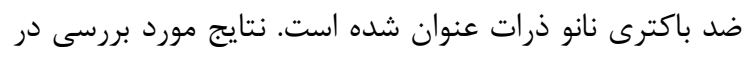
آزمون اين نمونهها مطابق با ادعاى شركت سازنده جوراب (مهيار)، دستمال كاغذى (نانوتكس) و نخ (زرنخ) و همجنين در تطابق با آزمون شستشوى نخ نايلون آنتىباكتريال به منظور بررسى يساب حاصله جهت تعيين ميزان نانونقره آزاد شده

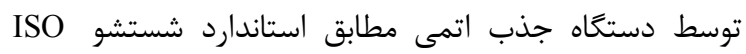

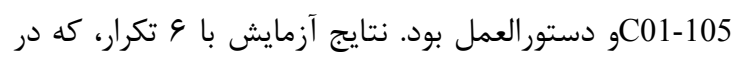

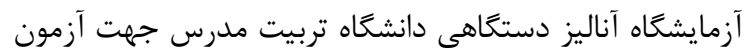




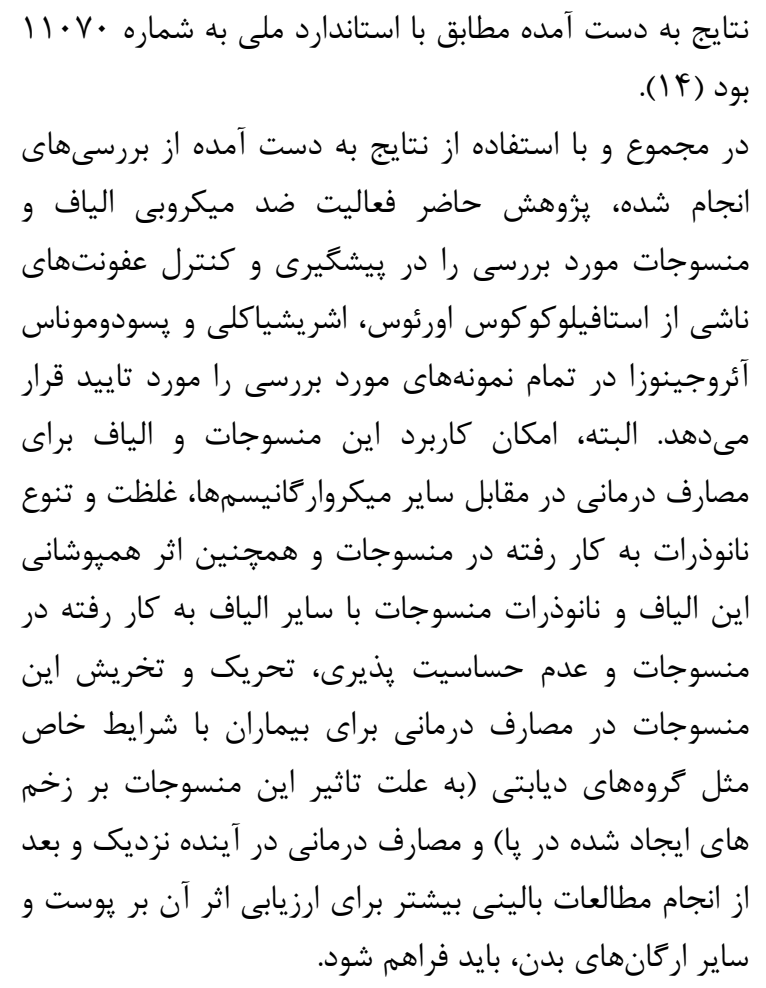

\section{تقدير و تشكر}

از همكارى و حمايت كميته فناورى نانو، سازمان غذا و دارو، و

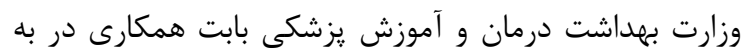

$$
\text { انجام رسيدن اين تحقيق سياسگزارى مىشود. }
$$

تحريك و تخريش يوستى ناشى از تماس حاد بخشى از اين

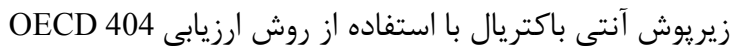

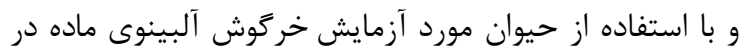

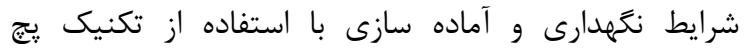
يوستى تهيه شده از نمونه هاى ارسالى استفاده شد. اين تست

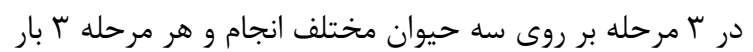

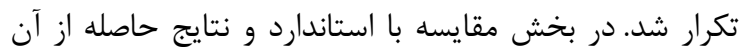

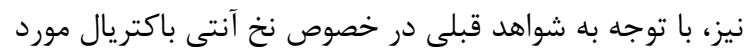

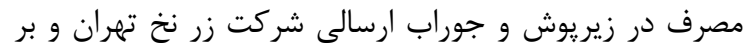
اساس تست انجام شده، ياسخهاى تحريك جلدى خفيف بر

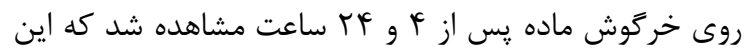
ياسخها با امتياز حداكثر r در يكى از r r حيوان مشاهده شده،

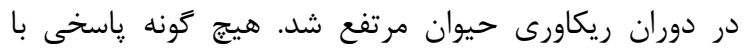

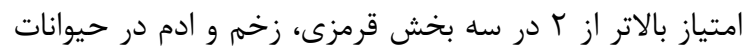
مورد آزمون ديده نشد و در شرايط آزمون حيوان سوم (نمونه كنترل كه نمونههاى ديخر مورد آزمون با آن مقايسه ميىشوند) بدون علامت بود. با توجه به شرايط مورد بررسى و آزمون كه مونه مونه

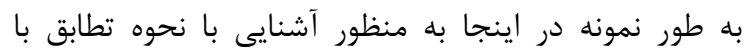

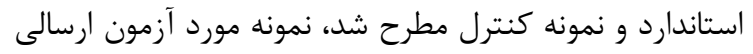
از شركت به آزمايشعاه كنترل كيفى فاقد خاصيت تحريك و ونه

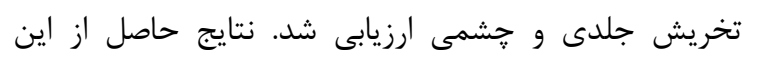

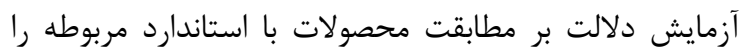

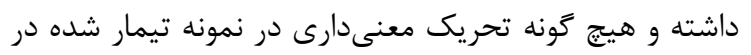

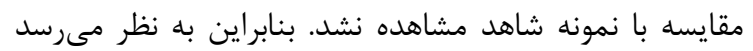

\section{REFERENCES}

1. Chen CY, Chiang CL. Preparation of cotton fibers with antibacterial silver nanoparticles. Mater Lett 2008: 62: 3607609.

2.Duncan T, Pillai, K. Release of engineered nanomaterials from polymer nanocomposites: diffusion, dissolution, and desorption. ACS Appl Mater Interfaces 2014: 7: 2-19.

3.Maurer EI, Sharma M, Schlager JJ, Hussain, SM. Systematic analysis of silver nanoparticle ionic dissolution by tangential flow filtration: toxicological implications. Nanotoxicology 2014: 8: 718-727.

4.Mc Gillicuddy E, Murray I, Kavanagh S, Morrison L, Fogarty A, Cormican M, et al. Silver nanoparticles in the environment: Sources, detection and ecotoxicology. Sci Total Environ 2007: 575: 231-246.

5.Zhao X, Bian F, Sun L, Cai L, Li L, Zhao Y. Microfluidic generation of nanomaterials for biomedical applications. Small. 2019:e1901943.

6.Zhang Z, Shen W, Xue J, Liu Y, Liu Y, Yan P, et al. Recent advances in synthetic methods and applications of silver nanostructures. Nanoscale Res Lett 2018; 13:54.

7.Naik K, Kowshik M. The silver lining: towards the responsible and limited usage of silver. J Appl Microbiol 2017; 123:1068-1087.

8.Mitrano DM, Rimmele E, Wichser A, Erni R, Height M, Nowack B. Presence of nanoparticles in wash water from conventional silver and nano-silver textiles. ACS Nano 2014: 8: 7208-19.

9.Lombi E, Donner E, Scheckel KG, Sekine R, Lorenz C, Von Goetz N, et al. Silver speciation and release in commercial antimicrobial textiles as influenced by washing. Chemosphere 2014: 111: 352-58. 
10.ASTM E 2859:2011- Standard Guide for Size Measurement of Nanoparticles Using Atomic Force Microscopy. Available from: astm.org/DATABASE.CART/HISTORICAL/E2859-11.htm

11.Duncan TV, Pillai K. Release of engineered nanomaterials from polymer nanocomposites: diffusion, dissolution, and desorption. ACS Appl Mater Interfaces 2015;7:2-19.

12.Lombi E, Donner E, Scheckel KG, Sekine R, Lorenz C, Von Goetz N, et al. Silver speciation and release in commercial antimicrobial textiles as influenced by washing. Chemosphere 2014; 111:352-8.

13.OECD Guideline for testing of Chemicals: TG 404- 2015: Acute Dermal Irritation/Corrosion. Available from: https://www.oecd.org/env/test-no-404-acute-dermal-irritation-corrosion-9789264242678-en.htm

14.National Standard of Iran 11070- Textile - Determination of Antibacterial Activity in Textile Goods. First revision. Available at: https://www.oecd.org/env/test-no-405-acute-eye-irritation-corrosion-9789264185333-en.htm

15.National Standard of Iran 21195- Nanotechnology - Antimicrobial Textile Goods - Test Methods. Available from: https://nano.ir/index.php?ctrl=news\&actn=news_view\&site_id=1\&lang=1\&id=57483

16.OECD Guideline for testing of Chemicals: TG 405. Available from: https://www.oecd.org/env/test-no-405-acuteeye-irritation-corrosion-9789264185333-en.htm

17.Korani M, Rezayat SM, Gilani K, Arbabi Bidgoli S, Adeli S. Acute and subchronic dermal toxicity of nanosilver in guinea pig. Int J Nanomedicine 2011;6:855-62.

18.Korani M, Rezayat SM, Arbabi Bidgoli S. Sub-chronic dermal toxicity of silver nanoparticles in Guinea pig: special emphasis to heart, bone and kidney toxicities. Iran J Pharm Res 2013;12:511-9.

19.Ghaffari S, Alihosseini F, Rezayat Sorkhabadi SM, Arbabi Bidgoli S, Mousavi SE, Haghighat S, et al. Nanotechnology in wound healing; semisolid dosage forms containing curcumin-ampicillin solid lipid nanoparticles, invitro, ex-vivo and in-vivo characteristics. Adv Pharm Bull 2018;8:395-400.

20.Azizi-Lalabadi M, Ehsani A, Alizadeh-Sani M, Khezerlou A, Mirzanajafi-Zanjani M, Divband B, et al. Nanoparticles and zeolites: Antibacterial effects and their mechanism against pathogens. Curr Pharm Biotechnol 2019 8. 